\title{
Review \\ Bench-to-bedside review: Rare and common viral infections in the intensive care unit - linking pathophysiology to clinical presentation
}

\author{
Nicholas Stollenwerk, Richart W Harper and Christian E Sandrock \\ Division of Pulmonary and Critical Care Medicine, University of California-Davis School of Medicine, Davis, CA, USA
}

Corresponding author: Christian Sandrock, cesandrock@ucdavis.edu

Published: 17 July 2008

Critical Care 2008, 12:219 (doi:10.1186/cc6917)

This article is online at http://ccforum.com/content/12/4/219

(c) 2008 BioMed Central Ltd

\begin{abstract}
Viral infections are common causes of respiratory tract disease in the outpatient setting but much less common in the intensive care unit. However, a finite number of viral agents cause respiratory tract disease in the intensive care unit. Some viruses, such as influenza, respiratory syncytial virus (RSV), cytomegalovirus (CMV), and varicella-zoster virus (VZV), are relatively common. Others, such as adenovirus, severe acute respiratory syndrome (SARS)coronavirus, Hantavirus, and the viral hemorrhagic fevers (VHFs), are rare but have an immense public health impact. Recognizing these viral etiologies becomes paramount in treatment, infection control, and public health measures. Therefore, a basic understanding of the pathogenesis of viral entry, replication, and host response is important for clinical diagnosis and initiating therapeutic options. This review discusses the basic pathophysiology leading to clinical presentations in a few common and rare, but important, viruses found in the intensive care unit: influenza, RSV, SARS, VZV, adenovirus, CMV, VHF, and Hantavirus.
\end{abstract}

\section{Introduction}

Viral infections are common causes for upper and lower respiratory tract infections and a frequent reason for outpatient office visits. Comparatively, viral respiratory infections are less common in the intensive care unit (ICU) setting but still play an important clinical role. Most viral respiratory infections in the ICU are community-associated cases with severe lower respiratory disease that can progress into respiratory failure and acute respiratory distress syndrome (ARDS) [1]. The remainder are infections seen in immunocompromised patients, such as transplantation [2,3]. In some instances (severe acute respiratory syndrome [SARS], influenza, and adenovirus), viral respiratory infections present with fulminant respiratory failure and ARDS, heralding a larger community outbreak [4]. In these situations, the newly recog- nized illness in an ICU patient might be the first presentation of a larger public health emergency.

The clinical presentation, treatment, outcome, and personal and institutional infection control differ greatly among the most common viral infections in the ICU. These differences are largely based on the viral structure, mode of transmission and cell entry, and host immunology and thus provide the foundation for the clinical presentation, virulence, and medical therapeutics of these viral infections. Therefore, a basic knowledge of the more common ICU viral respiratory pathogens will provide a framework for the clinical and research approaches for these infections. This review will focus on the basic epidemiology, virology, and host immune response for a few common or high-impact viral respiratory pathogens in the ICU: influenza, respiratory syncitial virus (RSV), SARS, varicella-zoster virus (VZV), adenovirus, cytomegalovirus (CMV), and viral hemorrhagic fever (VHF) (Table 1). With this basic foundation, clinical care, public health, and medical therapeutics for these viruses will be enhanced from the laboratory to the bedside.

\section{Influenza}

Influenza causes a clinically recognizable, systemic illness characterized by abrupt-onset fever, headache, myalgia, and malaise (the classic influenza-like illness) [5]. Influenza is subdivided into three distinct types: A, B, and C $[5,6]$. Influenza $A$ infects a variety of species, including birds, swine, horses, marine mammals, and humans $[5,6]$. Influenza $B$ infects only humans and predominates in children, and both influenza A and B cause yearly outbreaks. Respiratory symptoms are usually self-limited. However, a small number of

ARDS = acute respiratory distress syndrome; CMV = cytomegalovirus; HA = hemagglutinin; HFRS = hemorrhagic fever with renal syndrome; HPS = Hantavirus cardiopulmonary syndrome; ICU = intensive care unit; IL = interleukin; $\mathrm{MBL}=$ mannose-binding lectin; $\mathrm{MHC}=$ major histocompatibility complex; MIP-1 = macrophage inflammatory protein-1; NA = neuraminidase; RSV = respiratory syncytial virus; SARS = severe acute respiratory syndrome; SARS-CoV = severe acute respiratory syndrome-coronavirus; TNF = tumor necrosis factor; VHF $=$ viral hemorrhagic fever; VZV $=$ varicella-zoster virus. 
Table 1

\begin{tabular}{|c|c|c|c|c|c|c|c|}
\hline & Influenza & RSV & SARS-CoV & VZV & Adenovirus & CMV & VHF \\
\hline Virus family & $\begin{array}{l}\text { Orthomyxo- } \\
\text { virdae }\end{array}$ & $\begin{array}{l}\text { Paramyxo- } \\
\text { virdae }\end{array}$ & Coronaviridae & Herpesvirdae & Adenoviridae & Herpesviridae & Filoviridae \\
\hline $\begin{array}{l}\text { Epidemiologic } \\
\text { link }\end{array}$ & $\begin{array}{l}\text { Seasonal } \\
\text { epidemic }\end{array}$ & $\begin{array}{l}\text { Seasonal } \\
\text { epidemic, } \\
\text { immuno- } \\
\text { compromised } \\
\text { and transplant }\end{array}$ & $\begin{array}{l}\text { Laboratory } \\
\text { exposure on } \\
\text { known } \\
\text { infected } \\
\text { individual }\end{array}$ & $\begin{array}{l}\text { Contact with } \\
\text { infected } \\
\text { individual }\end{array}$ & $\begin{array}{l}\text { Military camps, } \\
\text { mental health } \\
\text { facilities }\end{array}$ & $\begin{array}{l}\text { Transplantation, } \\
\text { immuno- } \\
\text { suppressive } \\
\text { medications }\end{array}$ & $\begin{array}{l}\text { Endemic area or } \\
\text { contact with } \\
\text { infected individual }\end{array}$ \\
\hline $\begin{array}{l}\text { Pulmonary } \\
\text { clinical } \\
\text { findings }\end{array}$ & $\begin{array}{l}\text { Primary } \\
\text { alveolar } \\
\text { pneumonia }\end{array}$ & $\begin{array}{l}\text { Upper } \\
\text { respiratory tract } \\
\text { infection, } \\
\text { bronchiolitis, } \\
\text { pneumonia }\end{array}$ & $\begin{array}{l}\text { Rapid } \\
\text { progressive } \\
\text { pneumonia, } \\
\text { ARDS }\end{array}$ & $\begin{array}{l}\text { Primary } \\
\text { alveolar } \\
\text { pneumonia }\end{array}$ & $\begin{array}{l}\text { Alveolar } \\
\text { pneumonia } \\
\text { with bronchiolitis }\end{array}$ & $\begin{array}{l}\text { Interstitial } \\
\text { pneumonitis, } \\
\text { bronchiolitis }\end{array}$ & Alveolar edema \\
\hline Lipid envelope & Yes & Yes & Yes & Yes & No & Yes & Yes \\
\hline $\begin{array}{l}\text { Major receptor } \\
\text { for cell entry }\end{array}$ & Sialic acid & $\begin{array}{l}\text { RSV } \\
\text { glycoprotein G }\end{array}$ & $\begin{array}{l}\text { CD209L } \\
\text { ACE } 2\end{array}$ & $\begin{array}{l}\text { Glycoprotein } \\
C \text { and D }\end{array}$ & $\begin{array}{l}\text { Coksackie- } \\
\text { adenovirus } \\
\text { receptor }\end{array}$ & $\begin{array}{l}\text { Unknown, } \\
\text { involves } \\
\text { integrens }\end{array}$ & $\begin{array}{l}\text { Folate receptor } \\
\text { alpha }\end{array}$ \\
\hline $\begin{array}{l}\text { Primary cell } \\
\text { of infection }\end{array}$ & $\begin{array}{l}\text { Type } 1 \\
\text { respiratory } \\
\text { epithelium }\end{array}$ & $\begin{array}{l}\text { Type } 1 \\
\text { respiratory } \\
\text { epithelium }\end{array}$ & $\begin{array}{l}\text { Type } 1 \\
\text { respiratory } \\
\text { epithelium }\end{array}$ & $\begin{array}{l}\text { Macrophage } \\
\text { and dendritic } \\
\text { cells }\end{array}$ & $\begin{array}{l}\text { Type } 1 \\
\text { respiratory } \\
\text { epithelium }\end{array}$ & Multiple & $\begin{array}{l}\text { Macrophages and } \\
\text { dendritic cells }\end{array}$ \\
\hline Viremia & No & No & Yes & Yes & Yes & Yes & Yes \\
\hline $\begin{array}{l}\text { Primary host } \\
\text { immunity }\end{array}$ & Humoral & Humoral & Unknown & Cellular & Cellular & Cellular & Humoral \\
\hline
\end{tabular}

ARDS, acute respiratory distress syndrome; CMV, cytomegalovirus; RSV, respiratory syncytial virus; SARS-CoV, severe acute respiratory syndrome-coronavirus; VHF, viral hemorrhagic fever; VZV, varicella-zoster virus.

individuals can develop primary pneumonia, which can progress to ARDS [5]. The respiratory symptoms will persist or progress, and in a minority of cases ARDS can develop [5,7-9]. The combination of pneumonia and ARDS usually occurs in at-risk individuals, like individuals with chronic lung diseases, but has been described in healthy individuals as well.

The structure of influenza's viral envelope is important in viral infection and thus host cell immunity $[10,11]$. The envelope contains surface glycoproteins essential for virus entry into the host cell. The trimeric hemagglutinin (HA) structure undergoes limited proteolysis by host cellular proteases such as furin. HA then binds to specific sialosaccharides found on the surface of respiratory epithelial cells to initiate cell entry [12]. The neuraminidase (NA) is an enzyme that catalyzes the removal of terminal sialic acids from glycoproteins [12]. This helps degrade respiratory tract mucus and release viral progeny after cell infection and thus is necessary for subsequent viral entry to viral escape from the host cell [12]. Influenza $A$ is divided into subtypes based on $\mathrm{H}$ and $\mathrm{N}$ antigenicity [11]. All $\mathrm{H}$ subtypes have been found in multiple avian species and other animals. $\mathrm{H}_{1}, \mathrm{H} 2$, and $\mathrm{H} 3$ predominate in human disease seasonally, and more recently, avian subtypes such as $\mathrm{H} 5$ and $\mathrm{H} 7$ have increased in humans over the past decade [13-15].
Infection occurs when viruses containing aerosols are deposited into the upper respiratory tract epithelium [5]. In experimental volunteers, inoculation with small-particle aerosols more closely mimics natural disease than large drops into the nose, illustrating the easy transmission with coughing or sneezing $[16,17]$. The virus can attach $(\mathrm{HA})$ and penetrate the columnar epithelial cells. Predominantly human subtypes $(\mathrm{H} 1, \mathrm{H} 2$, and $\mathrm{H} 3)$ bind to alpha-2,6-galactose sialic acid found in ciliated human respiratory tract epithelium [18]. On the other hand, avian influenza subtypes (for example, H5N1) bind preferentially to alpha-2,3-galactose sialic acid, which is found in the gastrointestinal tract of water fowl, epithelial cells on human conjunctivae, and on human type 2 pneumocytes [18-20]. This preferential binding for specific sialic acid receptors illustrates the differences in clinical presentation seen with avian influenza infections in humans: conjunctivitis, diarrhea, and fulminant alveolar pneumonia [20]. Additionally, it underlies the difficulty with human-to-human transmission of avian strains as preferential binding to type 2 pneumocytes requires smaller particle aerosolization and deep inhalation into the alveoli rather than larger droplets seen with seasonal influenza transmission [20].

Host immunity occurs via a number of mechanisms. Upon receptor binding, a large cytokine response occurs, with interleukin (IL)-2, IL-6, and interferon gamma predominately 
[21]. This leads to extensive local inflammation with neutrophils and macrophages infiltrating the subepithelium of the respiratory tract. In cases of severe avian subtypes, a hemophagocytic syndrome and severe diffuse alveolar damage occur, causing the clinical findings of severe pneumonia and respiratory failure [21]. Within the alveolar macrophages and pneumocytes, major histocompatibility complex (MHC) I upregulation leads to antigen presentation of the $\mathrm{HA}$ and other subcapsular proteins $[22,23]$. This eventually leads to natural killer cell destruction of infected cells and the development of neutralizing antibodies (largely against HA) by day 14 of infection [22].

Treatment of active influenza involves antiviral agents and supportive care. The most effective therapy is prevention via vaccination and infection control $[4,5,13]$. Two types of antiviral medications have been used: (a) M2 inhibitors (amantadine and rimantadine) inhibit the M2 ion channel needed for viral replication [24]. These are not active against influenza $B$ and $\mathrm{C}$ and resistance is common in seasonal influenza. Thus, they should be used only in cases of known susceptibility. (b) The NA inhibitors, oseltamivir and zanamivir, have less resistance and prevent cleavage of sialic acid, which is necessary for a new virus to exit from the host cell [24]. Studies with the NA inhibitors show a reduction in symptom time and viral shedding, with peak effect when started within 48 hours of symptom onset $[4,5,13]$. However, treatment with NA inhibitors after 48 hours may provide some additional benefit but has not been fully studied [13]. Resistance is low within the community, but NA inhibitor resistance has already been described in clinical isolates from human cases of avian influenza.

\section{Respiratory syncytial virus}

Respiratory syncytial virus (RSV) is the most common cause of lower respiratory tract infections in children under 1 year of age, and healthy adults are infected repeatedly throughout their lives [25,26]. Adults typically have upper respiratory tract symptoms; however, some adults will develop lower respiratory tract infections, including bronchiolitis, pneumonia, and (rarely) ARDS [25-28]. The elderly and immunocompromised, particularly bone marrow transplant patients, are at highest risk of lower respiratory tract infection and respiratory failure [28]. In these cases, upper airway infection usually precedes lower tract infection by 1 to 3 days. Infection follows a pattern similar to influenza, with epidemics occurring in the winter months [25].

Inoculation occurs at the nasal or ocular mucosa via direct contact with secretions or infected fomites [29,30]. RSV has a lipoprotein envelope with surface glycoproteins that are important in host infection [31,32]. These glycoproteins act as cell fusion proteins, ultimately forming multinucleated giant cells ('syncytia'), assisting in cell-to-cell spread [31,32]. The virus replicates locally and then spreads to the epithelium of the bronchioles. From the bronchioles, the virus can then extend to the type 1 and 2 alveolar pneumocytes [31,33]. Infection leads to cellular (neutrophils, monocytes, and T cells) infiltration of the epithelium and supplying vasculature, with subsequent necrosis and proliferation [31,33]. This will cause the airway obstruction, air trapping, and increased airway resistance that are characteristic of RSV infection $[25,31,33]$. RSV infection is more specifically associated with IL-6 and macrophage inflammatory protein-1 (MIP-1) release [34-36]. Elevated levels of IL-6 and MIP-1 in the bronchioles have correlated with more severe disease [37].

Both droplet and contact transmissions are the main methods of spread, and thus hand washing, droplet isolation, and the use of personal protective equipment are all important in reducing viral spread $[29,30]$. Specific genotypes will predominate during a seasonal outbreak, and since the genotypes change annually, adult reinfections occur [32]. Treatment usually is focused on controlling bronchospasm and preventing spread to other patients and health care workers $[25,28]$. Bronchodilators and corticosteroids are used for bronchospasm, and aerosolized ribivirin has been used in severe and high-risk cases such as bone marrow transplants $[25,28]$. However, a recent study evaluating bronchiolitis in infants, in which over $50 \%$ of cases were caused by RSV, showed that corticosteroids had no effect on outcome [38].

\section{Severe acute respiratory distress syndrome}

SARS is caused by a novel coronavirus (SARS-CoV) that was first detected in $2003[39,40]$. The initial outbreak rapidly spread into a global epidemic, with cases reported from 29 countries. The fatality rate was $11 \%$, with most deaths in patients older than 65 and no deaths in children [39-41]. Since the initial epidemic in 2003, no new cases have been reported. SARS appears to clinically present as a two-stage illness. The initial prodrome, characterized by fever with or without rigors, malaise, headache, and myalgias, occurs an average of 7 days after contact with infected individuals [40-42]. Some patients also have mild respiratory symptoms or nausea and diarrhea. The respiratory phase appears to develop approximately 8 days after the onset of fever [40-42]. Forty-five percent of patients will develop hypoxemia and approximately $20 \%$ of these patients will progress to acute lung injury and require mechanical ventilation [40-42]. SARS-CoV appears to have originated from the horseshoe bat. The horseshoe bat appeared to be a natural reservoir for the virus and the civet cat acted as an intermediate host, allowing transmission to humans $[43,44]$.

Like RSV and influenza, SARS-CoV has a lipoprotein envelope, but unlike the RSV and influenza, the virus is assembled and obtains its envelope from the endoplasmic reticulum [45]. SARS-CoV, like other coronaviruses, starts with infection of the upper respiratory tract mucosa [40]. SARS-CoV binds to CD209L (L-SIGN) and ACE-2, two functional receptors on the respiratory tract epithelium $[46,47]$. After binding, local inflammation and edema increase. 
ACE-2 has a key protective role in acute lung injury by reducing alveolar fluid, and thus the binding of SARS-CoV to ACE-2 may contribute to the dysregulation of fluid balance in the alveolar space [48]. Additionally, low mannose-binding lectin (MBL) levels are thought to play a role in SARS pathogenesis [49]. In many respiratory infections, MBL prevents receptor attachment, activates complement, and enhances phagocytosis. In SARS-CoV infections, low or deficient levels of MBL have been noted, particularly associated with an MBL haplotype [49]. The binding of SARSCoV to ACE-2, along with lower levels of MBL, leads to higher viral levels, increased alveolar edema, and the severe acute respiratory failure associated with SARS-CoV.

Viral spread is by droplet transmission, although many cases suggest that airborne and contact routes also occur [39]. Spread to health care workers who wore appropriate personal protective equipment suggests an airborne mode, and additional spread by aerosol-generating procedures, such as resuscitation (cardiopulmonary resuscitation), medication nebulization, and noninvasive ventilation, further supports this mode [39,50-52]. The treatment for SARS is largely supportive with low tidal volume mechanical ventilation [40,53]. Numerous treatment strategies, including corticosteroids, ribavirin, immunoglobulin, and interferon, have been investigated in SARS: none has been demonstrated to provide clinical evidence of benefit.

\section{Varicella-zoster virus}

VZV infection routinely occurs during childhood, presenting with low-grade fever, malaise, pharyngitis, and a vesicular rash $[54,55]$. Primary disease occurs throughout the year and usually is self-limited in immunocompetent host. VZV pneumonia is rare in children. However, it is the most frequent complication in adults (20\%) and accounts for the majority of hospitalizations from VZV [56,57]. Varicella pneumonia develops insidiously, usually a few days after the onset of rash, and can progress to respiratory failure and ARDS $[56,57]$. Risk factors for VZV pneumonia and ARDS include pregnancy, smoking, and immunosuppression (malignancy, corticosteroids, HIV, and solid-organ transplant), but young healthy adults rarely develop ARDS [54,58]. Mortality for VZV pneumonia is $10 \%$ to $30 \%$, with a mortality of $50 \%$ when respiratory failure ensues [54,58]. Additional complications include encephalitis, hepatitis, and secondary skin and soft tissue infections.

VZV is a herpes virus, a common group of DNA viruses that have a lipid-containing envelope with surface glycoproteins [59]. Infection starts in the upper respiratory tract mucosa as the surface glycoprotiens allow for fusion of the lipid envelope with the respiratory cell membrane [60,61]. Upon cell entry, viral replication and assembly occur after integration of the viral genes into the cellular DNA [60,61]. Naked capsids then acquire their envelope at the nuclear membrane and are released into the perinuclear space where large vacuoles are formed, leading to the clinical vesicles $[60,61]$. Local replication and spread lead to seeding of the reticuloendothelial system and ultimately viremia, which leads to diffuse and scattered skin lesions associated with primary varicella [62,63]. Viral shedding can last from onset of fever until all lesions have crusted and pneumonia has improved. Both humoral immunity and cell-mediated immunity are involved in protection $[62,64]$. Antibodies are directed at the surface glycoprotein and lead to viral neutralization. Cellular immunity drives local inflammation, leading to cell repair and vacuole removal. The virus becomes latent within the dorsal root ganglia $[59,63]$. During latency, the viral DNA is located in the cytoplasm rather than integrated into nuclear DNA.

VZV is highly contagious and transmission is via respiratory droplets and direct contact with lesions [56,62]. The envelope is sensitive to detergent and air drying, which account for the lability of VZV on fomites. In adults who progress to pneumonia or ARDS, treatment with acyclovir and corticosteroids has been shown to lessen hospital and ICU stays $[62,65,66]$. In immunocompromised persons not previously exposed to VZV, varicella-zoster immune globulin has been shown to be useful for both prevention of disease and symptomatic improvement $[62,65,66]$.

\section{Adenovirus}

Adenovirus is the one of the most common causes of upper respiratory tract infections in adults and children $[67,68]$. Clinical disease usually is a self-limited upper respiratory tract infection associated with conjunctivitis; however, severe lower respiratory disease can occur in both high-risk and healthy individuals [67,69-71]. The combination of pneumonia and ARDS develops in a minority of individuals and usually is associated with conjunctivitis and other extrapulmonary manifestations, such as gastrointestinal disease, hepatitis, meningitis, and hemorrhagic cystitis [68]. The extrapulmonary complications, along with ARDS, are more frequent in transplant recipients. Pneumonia and ARDS appear to be more common with subtype $E$ type 4 and subgroups B type 7, but serogroup 35 also has been documented in mental health facilities [69-71]. Recent increases in respiratory diseases in adults have been noted over the past year with serotype 14 [72].

Over 51 human adenovirus subtypes exist and clinical syndromes vary among subtypes [53]. However, certain subtypes appear to have an increased likelihood of lower respiratory tract involvement and this appears to be related to the viral capsid proteins [73]. Unlike influenza, RSV, and SARS, adenovirus is a DNA virus covered by a protein capsid without a lipid envelope. Rodlike structures called fibers are one of three capsid protein types (hexons, pentons, and fibers) and these fibers are the attachment apparatus for viral adsorption to the cell [73]. Attachment occurs at the coxsackieadenovirus receptor, the same receptor as the coxsackie $B$ virus. The hexon capsid protein appears to have 
some antigenic sites that are common to all human adenoviruses and contains other sites that show type specificity [73]. Fiber antigen seems to be primarily typespecific with some group specificity, whereas the penton base antigen is common to the adenovirus family. Upon infection, respiratory epithelial cells express these capsid proteins on their surface, leading to direct $\mathrm{CD}^{+}$cytotoxic T-cell MHC class 1 killing of these cells [74]. Thus, epithelial destruction associated with submucosal edema drives the clinical findings of lower respiratory disease [67]. Additionally, neutralizing antibody is directed at the hexon type-specific antigen and provides some future protection against serotypes [74].

Adenovirus is relatively stable on environmental surfaces for long periods of time, and thus viral spread is largely associated with infected fomites $[53,67]$. Spread also occurs via droplet transmission. Treatment is largely supportive. For severe cases, especially in immunosuppressed patients, antiviral therapy has been attempted but no clinical studies exist [69-72]. In severe cases, especially in immunocompromised patients, ribavirin and cidofovir antiviral therapy has been attempted, but no controlled clinical trials exist.

\section{Cytomegalovirus}

CMV is a common viral infection that causes both primary and latent infections. Seroprevalence rates range from $60 \%$ to $70 \%$ in US adult populations $[75,76]$. CMV causes a wide spectrum of illness, ranging from an asymptomatic infection to a mononucleosis syndrome, organ-specific complications, and fulminant multisystem disease [77-79]. Immunocompetent patients are more likely to present with minimal to no symptoms, whereas immunocompromised patients are more likely to develop organ-specific complications and fulminant disease [77-79]. The most significant and severe disease syndromes are found in lung, liver, kidney, and heart transplant recipients [80]. Significant morbidity and mortality usually are confined to immunocompromised persons; however, previously healthy individuals can present with organ-specific complications or even present with fulminant disease $[78,80]$.

CMV is a member of the herpes virus family and, like other members of this family, is known for causing latent infections [75]. Like other herpes viruses, CMV is an enveloped virus with multiple surface glycoproteins. These glycoproteins are important for viral entry into host cells and are targets for host cell humoral and cell-mediated immunity $[75,81]$. The cellular protein that serves as the specific receptor for CMV entry has not been identified, but CMV infects cells by a process of endocytosis [37]. Once entry has occurred, CMV alters host immunity through the activation of multiple genes. One important CMV protein prevents cellular HLA-1 molecules from reaching the cell surface, preventing recognition and destruction by $\mathrm{CD}^{+} \mathrm{T}$ lymphocytes [82]. Thus, the CMV genome can remain in infected cells and avoid immune destruction, which accounts for its latency in clinical disease. Eventually, a cellular immune response, driven by high levels of anti-CMV CD4 ${ }^{+}$and CD8 ${ }^{+}$T cells, leads to control of the disease $[37,82,83]$. Antibodies against CMV do not provide significant immunity [83].

Avoiding immune detection gives CMV the ability to remain latent after infection, which contributes a great deal to serious CMV disease. Evidence for persistent CMV genomes and antigens exists in many tissues after initial infection, and CMV has been found in circulating mononuclear cells and in polymorphonuclear neutrophils [84]. The virus can be cultured from most bodily fluids, including blood, urine, stool, tears, semen, and breast milk, and from mucosal surfaces, including the throat and cervix [85-88]. Detection of cells that contain CMV intranuclear inclusions in renal epithelial tissue and in pulmonary secretions provides evidence that CMV may persist in these tissues as well. CMV antigens have also been detected in vascular endothelial cells; this site has been suggested as a cause of vascular inflammation and development of atherosclerosis [89]. When immune suppression occurs in patients by means of HIV infection or through immunosuppressive therapy, such as antilymphocyte antibody infusion, CMV can reactivate, producing end-organ disease $[80,83]$. Specifically from a pulmonary standpoint, CMV is common after lung transplantation, causing an acute pneumonitis or contributing to a chronic bronchiolitis [90]. In HIV patients, CMV pneumonitis is rare but postmortem studies suggest that pulmonary disease from CMV occurs at higher rates than previously recognized [90].

CMV is transmitted via many routes. Transmission has been observed among family members (thought to be secondary to close contact and viral shed from the upper respiratory tract), among children and employees at daycare centers, from sexual contact, blood and tissue exposure (seroconversion after transfusion of blood products or organ transplantation), and perinatally (during birth or from breast milk) [85-88]. There are several antiviral agents available for systemic treatment of CMV. These agents include ganciclovir, valgancicilovir, foscarnet, and cidofovir [9,37,91].

\section{Viral hemorrhagic fevers}

The VHFs include a wide number of geographically distributed viruses found worldwide, including Ebola and Marburg viruses, Rift Valley fever, Crimean Congo hemorrhagic fever, Lassa fever, yellow fever, and dengue fever. Ebola and Marburg viruses are in the family filoviridae [92-95]. Although the underlying pathophysiology differs slightly between the VHFs, Marburg and Ebola viruses serve as a classic template [92-95].

Marburg virus has a single species whereas Ebola has four different species that vary in virulence in humans [92-95]. The clinical manifestations of both Marburg and Ebola viruses are similar in presentation, with a higher mortality with Ebola Zaire 
( $75 \%$ to $90 \%$ ) than Marburg (25\% to $40 \%$ ) virus being the only major difference between them. The initial incubation period after exposure to the virus is 5 to 7 days, with clinical disease beginning with the onset of fever, chills, malaise, severe headache, nausea, vomiting, diarrhea, and abdominal pain [92-94,96]. With this initial infection, macrophages and dendritic cells initially are the site of viral replication, followed by spread to the reticuloendothelial system heralding the initial onset of symptoms [97]. As macrophages and other infected tissues undergo necrosis, an overwhelming cytokine response occurs, leading to abrupt prostration, stupor, and hypotension $[92,93,96,98]$. Particularly, tumor necrosis factor (TNF), IL-1, IL-6, macrophage chemotactic protein, and nitric oxide levels are markedly increased [98]. VHF-infected macrophages, along with noninfected macrophages stimulated by cytokines, release cell surface tissue factor, which subsequently triggers the extrinsic coagulation pathway $[97,98]$. The clinical and laboratory findings of impaired coagulation with increased conjunctival and soft tissue bleeding shortly follow $[95,98]$. In some cases, more massive hemorrhage can occur in the gastrointestinal and urinary tracts, and in rare instances, alveolar hemorrhage can occur $[95,96,98,99]$. The onset of maculopapular rash on the arms and trunk also appears to be classic and may be a very distinctive sign. Along with the bleeding and hypotension, multiorgan failure occurs, eventually leading to death $[95,96,98,99]$. The overwhelming viremia resulting in macrophage and dendritic cell apoptosis leads to impaired humoral immunity, which in turn leads to increase viral production [98]. This ultimately results in the rapid overwhelming shock seen with VHFs.

Transmission appears to occur through contact with nonhuman primates and infected individuals [95]. No specific therapy is available and patient management includes supportive care $[92,93,95,98]$. In a few cases in the Zaire outbreak of Ebola in 1995, whole blood with IgG antibodies against Ebola may have improved outcome, although subsequent analysis suggests that these patients were likely to survive even without this treatment [100].

\section{Hantavirus}

Hantavirus is one of four major genera within the family bunyaviridae, a family of more than 200 animal viruses spread via arthropod-vertebrate cycles [101-103]. Hantavirus causes two severe acute febrile illnesses: hemorrhagic fever with renal syndrome (HFRS) (found in the Old World) and Hantavirus cardiopulmonary syndrome (HPS) (found in the New World) [101-103]. HPS was first classified in the Southwestern US. A new species termed $\operatorname{Sin}$ Nombre virus was identified after an outbreak in the Four Corners region of the Southwestern US in 1993 [101-103]. In North America, disease largely has been reported in the Southwest and California, with cases reported in Canada, Europe, China, Chile, Argentina, and other parts of South America. Outbreaks are often cyclical and focal and are affected by weather and climatic variables and the effect this has on rodent populations [104].
Symptoms begin with a prodrome of fever, chills, and myalgias; HFRS and HPS also can be accompanied by abdominal pain and gastrointestinal disturbances [101-104]. In HPS, initially, there is an absence of upper respiratory symptoms. At about day 5, modest dry cough and dyspnea will develop. Due to the severe increase in vascular permeability associated with HPS, disease progresses rapidly (within hours) to respiratory failure, shock, ARDS, coagulopathy, and arrhythmias [104,105]. Resolution also can occur rapidly. If hypoxia is managed and shock is not fatal, the vascular leak reverses in a few days and recovery is apparently complete. Notably, thrombocytopenia with an immunoblast-predominant leukocytosis is characteristic of the early cardiopulmonary phase [104,105].

The exact mechanism for ARDS, shock, and coagulopathy is unclear, but it is suspected that the immune response, rather than the virus itself, causes the capillary leak and shock. The intense cellular immune response alters endothelial cell barrier function and is harmful. Hantavirus causes an increased release of TNF and alpha interferon and increased $\mathrm{MHC} \mathrm{I}$ antigen presentation [106,107]. There is also a more intense CD8 ${ }^{+}$T-cell response in sicker patients $[106,107]$. It appears to result from a massive acute capillary leak syndrome and shock-inducing mechanisms thought to be due to the release of kinins and cytokines [106,107]. The syndrome's clinical presentation, rapid resolution, and histopathologic findings of interstitial infiltrates of $T$ lymphocytes and alveolar pulmonary edema without marked necrosis support this underlying process. Treatment mainly is supportive, with extracorporeal membrane oxygenation being used in some cases [104,105]. Ribavirin has been effective in HFRS, but not HPS. Mortality remains at roughly $20 \%$.

\section{Conclusion}

Viral infections in the ICU are common in the outpatient setting but become less common in the ICU. However, a small number of viral infections can lower respiratory tract disease and subsequent respiratory failure. These viral pathogens vary greatly in clinical disease, from rapid and fulminant respiratory failure and shock (VHF) to chronic latent disease of immunosuppression (CMV). However, most of these viruses commonly have lipid envelopes, except for adenovirus, and all have surface proteins or glycoprotiens that allow for attachment, cell entry, and virulence. Host response to these infections varies from primarily cellular to

\section{This article is part of a review series on Infection, edited by Steven Opal.}

Other articles in the series can be found online at http://ccforum.com/articles/ theme-series.asp?series $=\mathrm{CC}$ Infection 
humoral. All can cause respiratory disease but a few are of great public health concern, particularly novel strains of influenza, adenovirus, SARS, and VHFs. An understanding of the basic viral pathogenesis, along with host response, allows for a foundation in treatment and public health response within the ICU.

\section{Competing interests}

The authors declare that they have no competing interests.

\section{References}

1. Mandell LA, Wunderink RG, Anzueto A, Bartlett JG, Campbell GD, Dean NC, Dowell SF, File TM Jr., Musher DM, Niederman MS, Torres A, Whitney CG; Infectious Diseases Society of America; American Thoracic Society: Infectious diseases society of america/american thoracic society consensus guidelines on the management of community-acquired pneumonia in adults. Clin Infect Dis 2007, 44 Suppl 2:S27-72.

2. Kao KC, Tsai YH, Wu YK, Chen NH, Hsieh MJ, Huang SF, Huang CC: Open lung biopsy in early-stage acute respiratory distress syndrome. Crit Care 2006, 10:R106.

3. Papazian L, Thomas P, Bregeon F, Garbe L, Zandotti C, Saux P, Gaillat F, Drancourt M, Auffray JP, Gouin F: Open-lung biopsy in patients with acute respiratory distress syndrome. Anesthesiology 1998, 88:935-944.

4. Muller MP, McGeer A: Febrile respiratory illness in the intensive care unit setting: an infection control perspective. Curr Opin Crit Care 2006, 12:37-42.

5. Monto AS, Gravenstein S, Elliott M, Colopy M, Schweinle J: Clinical signs and symptoms predicting influenza infection. Arch Intern Med 2000, 160:3243-3247.

6. Rohm C, Zhou N, Suss J, Mackenzie J, Webster RG: Characterization of a novel influenza hemagglutinin, H15: criteria for determination of influenza A subtypes. Virology 1996, 217: 508-516.

7. Lyytikainen O, Hoffmann E, Timm H, Schweiger B, Witte W, Vieth U, Ammon A, Petersen LR: Influenza A outbreak among adolescents in a ski hostel. Eur J Clin Microbiol Infect Dis 1998, 17:128-130.

8. Martin CM, Kunin CM, Gottlieb LS, Finland M: Asian influenza A in Boston, 1957-1958. II. Severe staphylococcal pneumonia complicating influenza. AMA Arch Intern Med 1959, 103:532542.

9. Masur H, Whitcup SM, Cartwright C, Polis M, Nussenblatt R: Advances in the management of AIDS-related cytomegalovirus retinitis. Ann Intern Med 1996, 125:126-136.

10. Masurel N, Marine WM: Recycling of Asian and Hong Kong influenza $\mathbf{A}$ virus hemagglutinins in man. Am J Epidemiol 1973, 97:44-49.

11. Wilson IA, Cox NJ: Structural basis of immune recognition of influenza virus hemagglutinin. Annu Rev Immunol 1990, 8:737771.

12. La Gruta NL, Kedzierska K, Stambas J, Doherty PC: A question of self-preservation: immunopathology in influenza virus infection. Immunol Cell Biol 2007, 85:85-92.

13. Wong SS, Yuen KY: Avian influenza virus infections in humans. Chest 2006, 129:156-168.

14. Beigel JH, Farrar J, Han AM, Hayden FG, Hyer R, de Jong MD, Lochindarat S, Nguyen TK, Nguyen TH, Tran TH, Nicoll A, Touch $\mathrm{S}$, Yuen KY; Writing Committee of the World Health Organization (WHO) Consultation on Human Influenza A/H5: Avian influenza A (H5N1) infection in humans. N Engl J Med 2005, 353:13741385 .

15. de Jong MD, Hien TT: Avian influenza A (H5N1). J Clin Virol 2006, 35:2-13.

16. Alford RH, Kasel JA, Gerone PJ, Knight V: Human influenza resulting from aerosol inhalation. Proc Soc Exp Biol Med 1966, 122:800-804.

17. Little JW, Douglas RG Jr., Hall WJ, Roth FK: Attenuated influenza produced by experimental intranasal inoculation. J Med Virol 1979, 3:177-188

18. Ha Y, Stevens DJ, Skehel JJ, Wiley DC: X-ray structures of H5 avian and $\mathrm{H} 9$ swine influenza virus hemagglutinins bound to avian and human receptor analogs. Proc Natl Acad Sci U S A 2001, 98:11181-11186.

19. Gamblin SJ, Haire LF, Russell RJ, Stevens DJ, Xiao B, Ha Y, Vasisht N, Steinhauer DA, Daniels RS, Elliot A, Wiley DC, Skehel $\mathrm{JJ}$ : The structure and receptor binding properties of the 1918 influenza hemagglutinin. Science 2004, 303:1838-1842.

20. van Riel D, Munster VJ, de Wit E, Rimmelzwaan GF, Fouchier RA, Osterhaus $A D$, Kuiken T: H5N1 virus attachment to lower respiratory tract. Science 2006, 312:399.

21. To KF, Chan PK, Chan KF, Lee WK, Lam WY, Wong KF, Tang NL, Tsang DN, Sung RY, Buckley TA, Tam JS, Cheng AF: Pathology of fatal human infection associated with avian influenza $A$ H5N1 virus. J Med Virol 2001, 63:242-246.

22. Katz JM, Lim W, Bridges CB, Rowe T, Hu-Primmer J, Lu X, Abernathy RA, Clarke M, Conn L, Kwong H, Lee M, Au G, Ho YY, Mak $\mathrm{KH}$, Cox NJ, Fukuda K: Antibody response in individuals infected with avian influenza A (H5N1) viruses and detection of anti-H5 antibody among household and social contacts. Infect Dis 1999, 180:1763-1770.

23. de Jong MD, Simmons CP, Thanh TT, Hien VM, Smith GJ, Chau TN, Hoang DM, Chau NV, Khanh TH, Dong VC, Qui PT, Cam BV, Ha do Q, Guan Y, Peiris JS, Chinh NT, Hien TT, Farrar J: Fatal outcome of human influenza A (H5N1) is associated with high viral load and hypercytokinemia. Nat Med 2006, 12:12031207.

24. Lynch JP 3rd, Walsh EE: Influenza: evolving strategies in treatment and prevention. Semin Respir Crit Care Med 2007, 28: 144-158.

25. Falsey AR, Hennessey PA, Formica MA, Cox C, Walsh EE: Respiratory syncytial virus infection in elderly and high-risk adults. N Engl J Med 2005, 352:1749-1759.

26. Walsh EE, Falsey AR, Hennessey PA: Respiratory syncytial and other virus infections in persons with chronic cardiopulmonary disease. Am J Respir Crit Care Med 1999, 160:791795.

27. O'Shea MK, Ryan MA, Hawksworth AW, Alsip BJ, Gray GC: Symptomatic respiratory syncytial virus infection in previously healthy young adults living in a crowded military environment. Clin Infect Dis 2005, 41:311-317.

28. Zaroukian MH, Kashyap GH, Wentworth BB: Respiratory syncytial virus infection: a cause of respiratory distress syndrome and pneumonia in adults. Am J Med Sci 1988, 295:218-222.

29. Hall CB, Douglas RG Jr.: Modes of transmission of respiratory syncytial virus. J Pediatr 1981, 99:100-103.

30. Hall CB, Douglas RG Jr., Schnabel KC, Geiman JM: Infectivity of respiratory syncytial virus by various routes of inoculation. Infect Immun 1981, 33:779-783.

31. Aherne W, Bird T, Court SD, Gardner PS, McQuillin J: Pathological changes in virus infections of the lower respiratory tract in children. J Clin Pathol 1970, 23:7-18.

32. Peret TC, Hall CB, Schnabel KC, Golub JA, Anderson LJ: Circulation patterns of genetically distinct group $A$ and $B$ strains of human respiratory syncytial virus in a community. J Gen Virol 1998, 79 (Pt 9):2221-2229.

33. Johnson JE, Gonzales RA, Olson SJ, Wright PF, Graham BS: The histopathology of fatal untreated human respiratory syncytial virus infection. Mod Pathol 2007, 20:108-119.

34. Garofalo RP, Patti J, Hintz KA, Hill V, Ogra PL, Welliver RC: Macrophage inflammatory protein-1alpha (not T helper type 2 cytokines) is associated with severe forms of respiratory syncytial virus bronchiolitis. $J$ Infect Dis 2001, 184:393-399.

35. Noah TL, Henderson FW, Wortman IA, Devlin RB, Handy J, Koren HS, Becker S: Nasal cytokine production in viral acute upper respiratory infection of childhood. J Infect Dis 1995, 171:584592.

36. Smyth RL, Fletcher JN, Thomas HM, Hart CA: Immunological responses to respiratory syncytial virus infection in infancy. Arch Dis Child 1997, 76:210-214.

37. Gandhi MK, Khanna R: Human cytomegalovirus: clinical aspects, immune regulation, and emerging treatments. Lancet Infect Dis 2004, 4:725-738.

38. Corneli HM, Zorc JJ, Majahan P, Shaw KN, Holubkov R, Reeves SD, Ruddy RM, Malik B, Nelson KA, Bregstein JS, Brown KM, Denenberg MN, Lillis KA, Cimpello LB, Tsung JW, Borgialli DA, Baskin MN, Teshome G, Goldstein MA, Monroe D, Dean JM, Kuppermann N; Bronchiolitis Study Group of the Pediatric Emergency Care Applied Research Network (PECARN): A multicenter, ran- 
domized, controlled trial of dexamethasone for bronchiolitis. N Engl J Med 2007, 357:331-339.

39. Christian MD, Poutanen SM, Loutfy MR, Muller MP, Low DE: Severe acute respiratory syndrome. Clin Infect Dis 2004, 38: 1420-1427.

40. Rainer TH: Severe acute respiratory syndrome: clinical features, diagnosis, and management. Curr Opin Pulm Med 2004, 10:159-165.

41. Peiris JS, Chu CM, Cheng VC, Chan KS, Hung IF, Poon LL, Law $\mathrm{KI}$, Tang BS, Hon TY, Chan CS, Chan KH, Ng JS, Zheng BJ, Ng WL, Lai RW, Guan Y, Yuen KY; HKU/UCH SARS Study Group: Clinical progression and viral load in a community outbreak of coronavirus-associated SARS pneumonia: a prospective study. Lancet 2003, 361:1767-1772.

42. Booth CM, Matukas LM, Tomlinson GA, Rachlis AR, Rose DB, Dwosh HA, Walmsley SL, Mazzulli T, Avendano M, Derkach P, Ephtimios IE, Kitai I, Mederski BD, Shadowitz SB, Gold WL, Hawryluck LA, Rea E, Chenkin JS, Cescon DW, Poutanen SM, Detsky AS: Clinical features and short-term outcomes of 144 patients with SARS in the greater Toronto area. JAMA 2003, 289:2801-2809.

43. Li W, Shi Z, Yu M, Ren W, Smith C, Epstein JH, Wang H, Crameri G, Hu Z, Zhang H, Zhang J, McEachern J, Field H, Daszak P, Eaton BT, Zhang S, Wang LF: Bats are natural reservoirs of SARS-like coronaviruses. Science 2005, 310:676-679.

44. Wang LF, Shi Z, Zhang S, Field H, Daszak P, Eaton BT: Review of bats and SARS. Emerg Infect Dis 2006, 12:1834-1840.

45. Lau SK, Woo PC, Li KS, Huang Y, Tsoi HW, Wong BH, Wong SS, Leung SY, Chan KH, Yuen KY: Severe acute respiratory syndrome coronavirus-like virus in Chinese horseshoe bats. Proc Natl Acad Sci U S A 2005, 102:14040-14045.

46. Jeffers SA, Tusell SM, Gillim-Ross L, Hemmila EM, Achenbach JE, Babcock GJ, Thomas WD Jr., Thackray LB, Young MD, Mason RJ, Ambrosino DM, Wentworth DE, Demartini JC, Holmes KV: CD209L (L-SIGN) is a receptor for severe acute respiratory syndrome coronavirus. Proc Natl Acad Sci U S A 2004, 101: 15748-15753.

47. Li W, Moore MJ, Vasilieva N, Sui J, Wong SK, Berne MA, Somasundaran M, Sullivan JL, Luzuriaga K, Greenough TC, Choe H, Farzan M: Angiotensin-converting enzyme 2 is a functional receptor for the SARS coronavirus. Nature 2003, 426:450-454.

48. Kuba K, Imai $Y$, Rao S, Gao H, Guo F, Guan B, Huan $Y$, Yang $P$, Zhang Y, Deng W, Bao L, Zhang B, Liu G, Wang Z, Chappell M, Liu Y, Zheng D, Leibbrandt A, Wada T, Slutsky AS, Liu D, Qin C, Jiang $C$, Penninger JM: A crucial role of angiotensin converting enzyme 2 (ACE2) in SARS coronavirus-induced lung injury. Nat Med 2005, 11:875-879.

49. Ip WK, Chan KH, Law HK, Tso GH, Kong EK, Wong WH, To YF, Yung RW, Chow EY, Au KL, Chan EY, Lim W, Jensenius JC, Turner MW, Peiris JS, Lau YL: Mannose-binding lectin in severe acute respiratory syndrome coronavirus infection. J Infect Dis 2005, 191:1697-1704.

50. Christian MD, Loutfy M, McDonald LC, Martinez KF, Ofner M, Wong T, Wallington T, Gold WL, Mederski B, Green K, Low DE; SARS Investigation Team: Possible SARS coronavirus transmission during cardiopulmonary resuscitation. Emerg Infect Dis 2004, 10:287-293.

51. Fowler RA, Scales DC, Ilan R: Evidence of airborne transmission of SARS. N Engl J Med 2004, 351:609-611; author reply 609-611.

52. Yu IT, Li Y, Wong TW, Tam W, Chan AT, Lee JH, Leung DY, Ho T: Evidence of airborne transmission of the severe acute respiratory syndrome virus. N Engl J Med 2004, 350:1731-1739.

53. Sandrock CE: Severe febrile respiratory illnesses as a cause of mass critical care. Respir Care 2008, 53:40-57.

54. Hockberger RS, Rothstein RJ: Varicella pneumonia in adults: a spectrum of disease. Ann Emerg med 1986, 15:931-934.

55. Straus SE, Ostrove JM, Inchauspe G, Felser JM, Freifeld A, Croen $\mathrm{KD}$, Sawyer MH: NIH conference. Varicella-zoster virus infections. Biology, natural history, treatment, and prevention. Ann Intern Med 1988, 108:221-237.

56. Triebwasser JH, Harris RE, Bryant RE, Rhoades ER: Varicella pneumonia in adults. Report of seven cases and a review of literature. Medicine 1967, 46:409-423.

57. Weber DM, Pellecchia JA: Varicella pneumonia: study of prevalence in adult men. JAMA 1965, 192:572-573.

58. Schlossberg D, Littman M: Varicella pneumonia. Arch Intern
Med 1988, 148:1630-1632

59. Sawyer MH, Ostrove JM, Felser JM, Straus SE: Mapping of the varicella zoster virus deoxypyrimidine kinase gene and preliminary identification of its transcript. Virology 1986, 149:1-9.

60. Achong BG, Meurisse EV: Observations on the fine structure and replication of varicella virus in cultivated human amnion cells. J Gen Virol 1968, 3:305-308.

61. Grose C, Perrotta DM, Brunell PA, Smith GC: Cell-free varicellazoster virus in cultured human melanoma cells. J Gen Virol 1979, 43:15-27.

62. Cohen Jl, Brunell PA, Straus SE, Krause PR: Recent advances in varicella-zoster virus infection. Ann Intern Med 1999, 130:922932.

63. Ozaki T, Ichikawa T, Matsui Y, Nagai T, Asano Y, Yamanishi K, Takahashi M: Viremic phase in nonimmunocompromised children with varicella. J Pediatr 1984, 104:85-87.

64. Feldman S: Varicella-zoster virus pneumonitis. Chest 1994, 106(1 Suppl):22S-27S.

65. Haake DA, Zakowski PC, Haake DL, Bryson YJ: Early treatment with acyclovir for varicella pneumonia in otherwise healthy adults: retrospective controlled study and review. Rev Infect Dis 1990, 12:788-798.

66. Mer M, Richards GA: Corticosteroids in life-threatening varicella pneumonia. Chest 1998, 114:426-431.

67. Russell KL, Broderick MP, Franklin SE, Blyn LB, Freed NE, Moradi E, Ecker DJ, Kammerer PE, Osuna MA, Kajon AE, Morn CB, Ryan MA: Transmission dynamics and prospective environmental sampling of adenovirus in a military recruit setting. $J$ Infect Dis 2006, 194:877-885

68. Yang E, Rubin BK: 'Childhood' viruses as a cause of pneumonia in adults. Semin Respir Infect 1995, 10:232-243.

69. Two fatal cases of adenovirus-related illness in previously healthy young adults-Illinois, 2000. MMWR 2001, 50:553555.

70. Klinger JR, Sanchez MP, Curtin LA, Durkin M, Matyas B: Multiple cases of life-threatening adenovirus pneumonia in a mental health care center. Am J Respir Crit Care Med 1998, 157:645649.

71. Sanchez MP, Erdman DD, Torok TJ, Freeman CJ, Matyas BT: Outbreak of adenovirus 35 pneumonia among adult residents and staff of a chronic care psychiatric facility. J Infect Dis 1997, 176:760-763.

72. Acute respiratory disease associated with adenovirus serotype 14-four states, 2006-2007. MMWR 2007, 56:1181-1184.

73. Hayashi S, Hogg JC: Adenovirus infections and lung disease. Curr Opin Pharmacol 2007, 7:237-243.

74. Tang J, Olive M, Pulmanausahakul R, Schnell M, Flomenberg N, Eisenlohr L, Flomenberg P: Human $\mathrm{CD}^{+}$cytotoxic $\mathrm{T}$ cell responses to adenovirus capsid proteins. Virology 2006, 350: 312-322.

75. Ho M: Epidemiology of cytomegalovirus infections. Rev Infect Dis 1990, 12 Suppl 7:S701-710.

76. Zhang LJ, Hanff $P$, Rutherford $C$, Churchill WH, Crumpacker CS: Detection of human cytomegalovirus DNA, RNA, and antibody in normal donor blood. J Infect Dis 1995, 171:1002-1006.

77. Cohen Jl, Corey GR: Cytomegalovirus infection in the normal host. Medicine 1985, 64:100-114.

78. Eddleston M, Peacock S, Juniper M, Warrell DA: Severe cytomegalovirus infection in immunocompetent patients. Clin Infect Dis 1997, 24:52-56.

79. Horwitz CA, Henle W, Henle G, Snover D, Rudnick H, Balfour HH Jr., Mazur MH, Watson R, Schwartz B, Muller N: Clinical and laboratory evaluation of cytomegalovirus-induced mononucleosis in previously healthy individuals. Report of 82 cases. Medicine 1986, 65:124-134.

80. Meyers JD, Flournoy N, Thomas ED: Risk factors for cytomegalovirus infection after human marrow transplantation. $J$ Infect Dis 1986, 153:478-488.

81. Adler SP: Molecular epidemiology of cytomegalovirus: viral transmission among children attending a day care center, their parents, and caretakers. J Pediatr 1988, 112:366-372.

82. Beersma MF, Bijlmakers MJ, Ploegh HL: Human cytomegalovirus down-regulates HLA class I expression by reducing the stability of class I H chains. J Immunol 1993, 151:44554464 .

83. Singh N, Dummer JS, Kusne S, Breinig MK, Armstrong JA, Makowka L, Starzl TE, Ho M: Infections with cytomegalovirus 
and other herpesviruses in 121 liver transplant recipients: transmission by donated organ and the effect of OKT3 antibodies. J Infect Dis 1988, 158:124-131.

84. Rinaldo $\mathrm{CR}$ Jr., Black $\mathrm{PH}$, Hirsch MS: Interaction of cytomegalovirus with leukocytes from patients with mononucleosis due to cytomegalovirus. J Infect Dis 1977, 136:667678.

85. Evans AS: Infectious mononucleosis and related syndromes. Am J Med Sci 1978, 276:325-339.

86. Handsfield HH, Chandler SH, Caine VA, Meyers JD, Corey L, Medeiros $E$, McDougall JK: Cytomegalovirus infection in sex partners: evidence for sexual transmission. J Infect Dis 1985, 151:344-348.

87. Pass RF, Little EA, Stagno S, Britt WJ, Alford CA: Young children as a probable source of maternal and congenital cytomegalovirus infection. $N$ Engl J Med 1987, 316:13661370.

88. Prince AM, Szmuness W, Millian SJ, David DS: A serologic study of cytomegalovirus infections associated with blood transfusions. N Engl J Med 1971, 284:1125-1131.

89. Kijpittayarit-Arthurs S, Eid AJ, Kremers WK, Pedersen RA, Dierkhising RA, Patel R, Razonable RR: Clinical features and outcomes of delayed-onset primary cytomegalovirus disease in cardiac transplant recipients. J Heart Lung Transplant 2007, 26:1019-1024.

90. Steininger C: Clinical relevance of cytomegalovirus infection in patients with disorders of the immune system. Clin Microbiol Infect 2007, 13:953-963.

91. Crumpacker CS: Ganciclovir. N Engl J Med 1996, 335:721-729.

92. Ebola: the virus and the disease. Wkly Epidemiol Rec 1999, 74:89.

93. Marburg haemorrhagic fever, Angola-update. Wkly Epidemiol $\operatorname{Rec} 2005,80: 125-126$.

94. Bausch DG, Borchert M, Grein T, Roth C, Swanepoel R, Libande ML, Talarmin A, Bertherat E, Muyembe-Tamfum JJ, Tugume B, Colebunders R, Kondé KM, Pirad P, Olinda LL, Rodier GR, Campbell P, Tomori O, Ksiazek TG, Rollin PE: Risk factors for Marburg hemorrhagic fever, Democratic Republic of the Congo. Emerg Infect Dis 2003, 9:1531-1537.

95. Peters CJ: Emerging infections-Ebola and other filoviruses. West J Med 1996, 164:36-38.

96. Bwaka MA, Bonnet MJ, Calain P, Colebunders R, De Roo A Guimard Y, Katwiki KR, Kibadi K, Kipasa MA, Kuvula KJ, Mapanda BB, Massamba M, Mupapa KD, Muyembe-Tamfum JJ, Ndaberey E, Peters CJ, Rollin PE, Van den Enden E, Van den Enden E: Ebola hemorrhagic fever in Kikwit, Democratic Republic of the Congo: clinical observations in 103 patients. J Infect Dis 1999, 179 Suppl 1:S1-7.

97. Bray M, Geisbert TW: Ebola virus: the role of macrophages and dendritic cells in the pathogenesis of Ebola hemorrhagic fever. Int J Biochem Cell Biol 2005, 37:1560-1566.

98. Mahanty S, Bray M: Pathogenesis of filoviral haemorrhagic fevers. Lancet Infect Dis 2004, 4:487-498.

99. Emond RT, Evans B, Bowen ET, Lloyd G: A case of Ebola virus infection. Br Med J 1977, 2:541-544.

100. Mupapa K, Massamba M, Kibadi K, Kuvula K, Bwaka A, Kipasa M, Colebunders R, Muyembe-Tamfum JJ: Treatment of Ebola hemorrhagic fever with blood transfusions from convalescent patients. International Scientific and Technical Committee. Infect Dis 1999, 179 Suppl 1:S18-23.

101. Ksiazek TG, Peters CJ, Rollin PE, Zaki S, Nichol S, Spiropoulou C, Morzunov S, Feldmann H, Sanchez A, Khan AS, Eaton BT: Identification of a new North American hantavirus that causes acute pulmonary insufficiency. Am J Trop Med Hyg 1995, 52:117123.

102. Nolte KB, Feddersen RM, Foucar K, Zaki SR, Koster FT, Madar D, Merlin TL, McFeeley PJ, Umland ET, Zumwalt RE: Hantavirus pulmonary syndrome in the United States: a pathological description of a disease caused by a new agent. Hum Pathol 1995, 26:110-120.

103. Zaki SR, Greer PW, Coffield LM, Goldsmith CS, Nolte KB, Foucar K, Feddersen RM, Zumwalt RE, Miller GL, Khan AS: Hantavirus pulmonary syndrome. Pathogenesis of an emerging infectious disease. Am J Pathol 1995, 146:552-579.

104. Peters CJ, Khan AS: Hantavirus pulmonary syndrome: the new American hemorrhagic fever. Clin Infect Dis 2002, 34:12241231.
105. Peters CJ, Simpson GL, Levy H: Spectrum of hantavirus infection: hemorrhagic fever with renal syndrome and hantavirus pulmonary syndrome. Annu Rev Med 1999, 50:531-545.

106. Kilpatrick ED, Terajima M, Koster FT, Catalina MD, Cruz J, Ennis FA: Role of specific CD8 ${ }^{+}$T cells in the severity of a fulminant zoonotic viral hemorrhagic fever, hantavirus pulmonary syndrome. J Immuno/ 2004, 172:3297-3304.

107. Raftery MJ, Kraus AA, Ulrich R, Kruger DH, Schonrich G: Hantavirus infection of dendritic cells. J Virol 2002, 76:1072410733. 